\title{
SOCIAL PROBLEM-SOLVING IN THE CLASSROOM
}

\author{
Zita Gál ${ }^{1}$, \& László Kasik ${ }^{2}$ \\ ${ }^{1}$ University of Szeged, Institute of Psychology / Social Competence Research Group (Hungary) \\ ${ }^{2}$ University of Szeged, Institute of Education / Social Competence Research Group (Hungary)
}

\begin{abstract}
In Hungary, the examinations of social problem-solving and their factors mainly carried out by self-reported questionnaires both among adolescents and adults. On the other hand, it is necessary to apply other research methods in order to identify and understand interpersonal problems and solution processes. In our current research, we used observation to identify student-student and teacher-student problems during a lesson. The study occurred in 2017, when 34 lessons were observed (in all grades except 3 and 4). Among these, 8 took place in lower primary schools (6-10-year-olds), 12 in upper primary schools (10-14-year-olds), 14 in high schools (14-18-year-olds). We carried out the observations using a set of criterias established by our research group based on Chang et al. (2004), Eskin (2012) and Strough \& Kenner (2012): the source of the problem, the subject of the problem, time perspective, frequency, organization, attitude, feasibility, problem solving styles and strategies, relationship between the members, behaviour of the teachers. The identified problems (based on age and gender) more or less are the same as we found during previous researches carried out by questionnaires: in lower primary school it is the mockery, and later the physical and verbal aggression which appears to be the main problems of the students. In the case of mockery and verbal aggression it is clear that they want to settle their differences as soon as possible. We experienced both in the questionnaire using researches and this observation, that negative orientation manifests in the verbal expression of inaccessibility. Teachers, except teachers in lower primary school, also have negative orientation towards a problem, and they think of a problem as a distractor, so their aim was the fast, behaviour-focused elimination of the situation. The problem-solving in upper primary and high schools were clearly teacher controlled, they immediately gave instructions to the students how to solve it based on their own consideration. We did not experience any kind of discussions, rethinking or evaluation of the situation among teachers. What we saw pays the attention to effect of the problems to classroom work, and interpersonal problems can influence students subject attitude and learning motivation. In the future, we are going to carry out other observations as well, and also planning to use a questionnaire to analyze as many aspects of problems solving as possible. This way we could get more and more precise data in order to develop a program for students and teachers.
\end{abstract}

Keywords: Social problem solving; classroom observation; behavior of teachers and students.

\section{Introduction}

Following observations at schools, Singleton and Asher (1977) categorised students' interpersonal problems. The most common of them among children and adolescents were insulting, decrying, looking down and physical abuse. In both cases of research, students stated problems which other people do not regard as problems but positive occurrences (e.g., receiving a gift), which reinforced earlier conclusions of the relative nature of problems and drew attention to the dependence of problems on social environments (only disadvantaged children gave such an example). Similar problem groups were revealed among primary and secondary school (7-18-year-old) students (Kasik \& Gál, 2015; Kasik, 2015): the most frequent problems claimed among lower year students were mockery, telling on each other and exclusion; among upper year students they were exclusion, physical abuse by peers and favouritism by teachers; and among secondary school students they were teasing and verbal abuse by peers. Parent-related problems appeared in a significant proportion on the problem list even among lower year students and this only grew among adolescents (physical and verbal abuse by parents, parents' problems related to alcohol, and family feuds and fights also in relation to those). 
Based on the work done by Bedell et al. (1980), Chang et al. (2004), D'Zurilla and Goldfried (1971), Eskin (2012), Hunt (1965), Singleton and Asher (1977) and Strough and Kenner (2012), we summarised the aspects used to interpret social problems in Table 1.

Table 1. Aspects of interpreting social problems.

\begin{tabular}{|c|c|}
\hline Main aspects & Sub-aspects \\
\hline Origin & $\begin{array}{ll}- & \text { Own (goal, need, interest, attribute) } \\
\text { - } & \text { Another person, others (goal, need, interest, attribute) } \\
\text { - } & \text { Environment, situation, social task } \\
\text { - } & \text { Group and social process }\end{array}$ \\
\hline Definition & $\begin{array}{ll} & \text { Well-defined } \\
- & \text { Less well-defined or not well-defined }\end{array}$ \\
\hline Manifestation & $\begin{array}{ll} & \text { In behaviour } \\
\text { - } & \text { In the expression of thoughts, feelings }\end{array}$ \\
\hline Chronology & $\begin{array}{ll}\text { - } & \text { Happening in the present or past } \\
\text { - } & \text { Happening in the future (possibly or certainly) }\end{array}$ \\
\hline Frequency & $\begin{array}{ll}- & \text { Occurs once or rarely } \\
\text { - } & \text { Occurs multiple times (repeats frequently) } \\
\text { - } & \text { Nearly constant } \\
\end{array}$ \\
\hline Consequence & $\begin{array}{ll}\text { - } & \text { Small degree } \\
\text { - } & \text { Considerable impact on how one leads his/her life }\end{array}$ \\
\hline Relation & $\begin{array}{ll}\text { - } & \text { Negative } \\
\text { - } & \text { Positive } \\
\end{array}$ \\
\hline Organisation & $\begin{array}{ll}\text { - } & \text { No connection with another (isolated) } \\
\text { - } & \text { Few causal relations } \\
\text { - } & \text { Many, forming a hierarchic system, causal relation }\end{array}$ \\
\hline Connection of members & $\begin{array}{ll}\text { - } & \text { Interpreted in a submissive relation } \\
\text { - } & \text { Interpreted in a coordinative relation }\end{array}$ \\
\hline Solvability & $\begin{array}{ll} & \text { Solvable (necessary, possible) } \\
\text { - } & \text { Unsolvable (not needed, not possible) } \\
\end{array}$ \\
\hline
\end{tabular}

The mode of problem solving is influenced by a considerable number of factors. Of these, family background emerges during childhood and adulthood as well, especially with regard to parents' problem solving and the examples they provide. With the advancement of age, peers' influence (in terms of their behaviour, suppositions and expectations) grows exponentially and teachers also play an influential role with their suppositions, expectations, the way they disciple and the examples they provide (Webster-Stratton, 2011). According to Webster-Stratton (2011), the effectiveness of problem-solving in the classroom is influenced by the system of values and norms mediated by the teacher; their problem-solving style; students' personal traits (e.g., communication and problem-solving ability, family examples for problem-solving); the network of power, emotions and communication in the group; and the emotional and confidential relation between the teacher and the student.

Based on Goldstein's research (1999), teachers teaching 7-12-year-olds dedicate more time to understanding and dealing with a problem, they use positive reinforcement, talk about proper behaviour and problem-solving strategies more often than those who teach adolescents (12-18-year-olds) as they aim to end problematic situations in order to maximise the time dedicated to mediating the material to be learnt. These teachers approach problems as factors of interference; however, this does not appear to be an effective strategy in terms of students' social development. In fact, it often serves as a negative example and can thus reinforce non-adequate forms of avoidance (e.g., negligence) as well as a negative approach to problems, the parts of which are insolvability or the feeling of pointlessness of making an effort to solve the problem.

\section{Aims and methods}

The aim of classroom observations carried out during spring 2017 was to identify interpersonal problems, their manifestations, styles and modes of solution between students and in student-teacher relationships. We received directorial authorisation in all schools (in four Hungarian counties) to carry out our observations. The lessons were chosen randomly, and the teachers were told that our aim was to see teaching methodologies and students' reactions to their impact. 
All the lessons were observed by two teacher trainees who were trained by the researchers and who positioned themselves in the back of the classrooms. They saw 34 lessons altogether (all years, except 3 and 4): 8 of these were at lower primary school (ethics, mathematics, geography, foreign language); 12 were at upper primary school (biology, physics, Hungarian grammar, mathematics, geography, foreign language); and 14 were at secondary school (Hungarian grammar and literature, mathematics, physics, geography, foreign language). Of the 14 secondary school lessons, 10 took place at a (four-year) grammar school and 4 took place at a technical grammar school (formerly: technical college). Of the 34 teachers, 7 were male and 27 were female, all of them between the ages of 35 and 45 , and with 10 to 20 years of teaching experience.

The observations were carried out by the observers based on a system of aspects (Table 2) as developed by us which was based on models and research methods presented in the theoretical part.

Table 2. Aspects of observation.

\begin{tabular}{|c|c|}
\hline Main aspects & Sub-aspects \\
\hline Characteristics of the class & $\begin{array}{l}\text { - Type of school (primary school, secondary school) } \\
\text { - } \quad \text { Year } \\
\text { - Number of students (present) } \\
\text { - } \quad \text { Desk arrangement (e.g., in rows, U-shape, circular, in groups) } \\
\text { - } \quad \text { Place of teacher's desk (e.g., in the forefront, on the side, in the middle) }\end{array}$ \\
\hline Source of the problem & $\begin{array}{l}\text { - Among who did the problem emerge: student-student, student-teacher } \\
\text { - How many are involved } \\
\text { - Distribution of sexes }\end{array}$ \\
\hline Subject & $\begin{array}{l}\text { - What is the problem based on what has been said (e.g., interest, value, } \\
\text { communication style, attribute) }\end{array}$ \\
\hline Chronology & $\begin{array}{l}\text { - Happened during the lesson } \\
\text { - Happened in the past and mentioned during the lesson } \\
\text { - Will happen in the future (possibly or certainly) }\end{array}$ \\
\hline Frequency & $\begin{array}{l}\text { - } \text { Expressed once } \\
\text { - Recurring during the lesson } \\
\text { - Permeates the entirety of the lesson }\end{array}$ \\
\hline Organisation & $\begin{array}{l}\text { - No connection with another (isolated) } \\
\text { - Few causal relations } \\
\text { - Many, forming a hierarchic system, causal relation }\end{array}$ \\
\hline Relation & $\begin{array}{l}\text { - Negative } \\
\text { - Positive }\end{array}$ \\
\hline Statements about solvability & $\begin{array}{l}\text { - Solvable (necessary, possible) } \\
\text { - Unsolvable (not needed, not possible) }\end{array}$ \\
\hline $\begin{array}{r}\text { Styles and strategies of } \\
\text { solution }\end{array}$ & $\begin{array}{l}\text { - Styles: rational, impulsive, avoiding } \\
\text { - Strategies: talking it through, aspiring to talk it through, making a } \\
\text { compromise, 'defeating' the other one, verbal/physical aggression }\end{array}$ \\
\hline $\begin{array}{r}\text { Connection between } \\
\text { members }\end{array}$ & $\begin{array}{ll}\text { - } & \text { Submission } \\
\text { - } & \text { Coordination } \\
\end{array}$ \\
\hline Teacher's behaviour & $\begin{array}{l}\text { - How does (s)he approaches the problem situation, how does (s)he reacts } \\
\text { - What does (s)he says during the solution }\end{array}$ \\
\hline
\end{tabular}

The observers were asked to make a report of all the situations that they deemed problematic; however, only those situations were analysed which manifested in direct, open communication. Therefore, the 45 instances of being on the phone, six instances of sending messages under the table, two instances of doing crosswords and four instances of reading magazines or books are not included in the analysis - none of these became a problem source (or the teacher did not want to make it one; we do not have insight into this). Based on the system of aspects, all the observers wrote detailed records and another evaluator, who was not present during the lesson, also analysed them. Following this, what was seen was analysed and talked through in smaller groups. No significant discrepancy was noticed between those who observed the same classes; it was only with regard to the reason behind certain problems and their consequences that different opinions emerged. 


\section{Results}

The interpersonal problems identified during the observation are in line with the formerly discovered ones, even in terms of age and sex (Kasik, 2015; Kasik \& Gál, 2014, 2016): in lower years, mockery emerges as the main problem while physical and verbal abuse emerges in upper years. Favouritism by the teacher, one of the most frequent student-teacher problems identified, was not seen by the observers during these lessons. Of all the problem situations among students, it was apparent from communication between them on two occasions (mockery, verbal absuse) that they wanted to solve the disagreement as soon as possible. It was seen among secondary school students that negative orientation is closely connected to the thought of insolvability (e.g. in the case of verbal abuse: 'Leave me alone, I do not want to deal with this. - I do not even care about you, you do not even understand.'). This supports the data from the questionnaire: negative orientation towards the problem and its solution becomes more and more prominent in adolescence.

Teachers' ability to recognise the situation, their intention for the problem situation, their communication technique and their relationship with the children defines how students interpret and deal with the problem and could counterpoint the often non-adequate social problem-solving style and mode acquired as part of the family socialisation (Webster-Stratton, 2011). Based on the observations, all teachers except lower primary school teachers regarded the problems that emerge between students and students and teachers as trouble, uncomfortable and as an obstacle; their aim was to quickly put an end to the situation. It was also with the exception of lower year teachers that their orientation towards the problem situation was significantly negative. This is in accordance with Goldstein's conclusion (1999) that pre-adolescent and adolescent students' problems are dealt with in a different way by teachers. In the case of lower year teachers, this can be accounted for by the number of hours spent with children (higher for lower year teachers), which enables them to get to know them better in terms of, among many things, their problems and the reasons behind them as well as their problem-solving styles and behaviour. Age-related differences in social attributes can be an important accounting factor too (e.g. emotion control, communication with a person of authority).

Problem-solving among upper primary school and secondary school teachers (both in terms of student-student and student-teacher problems) was largely dominated by them; they state what the good solution is, and they order its execution right away. It could not be even seen in the case of problems between students that they let them deal with it; they formed a suggestion for the solution. In the case of verbal and physical abuse as well as upon instances of taking liberties and scoffing, teachers do not really deal with what could be in the background of these based on their reactions. For example, what the reason behind scoffing could be (e.g. the suppression of some sort of past event), why an argument resulted in the beating of the other one, what they said to each other, why they said that. In addition to the behavioural approach, the acknowledgement of emotions and thoughts fails even though this is important both in terms of dealing with the problems and what there is behind them, and this would be of significant importance in early and later adolescence as well.

Though to varying degrees, but all teachers drew students' attention to their place in the hierarchy and their own position (e.g. in the case of taking liberties: 'My child, you cannot lecture me. '; 'Know who you are speaking to.'). Their communication was based on authority and they showed offence. Burnout can be hypothesised in the case of those teachers who utilised shaming, which typically manifests as loss of control in a tense situation (Petróczi, 2007). This is supported by the fact that this happened in the presence of an observer as well as running out of the classroom. The question arises: what does the teacher do when (s)he is alone with the children?

Examples were also seen where the problems that manifest themselves during the lesson have serious precursors; the events that took place outside of the lesson continue into it, emerge as even more complex problems (physical abuse) and they continue unless the situation is dealt with. Thinking and talking things through, evaluating the problem situation after it was dealt with, were not observed either. According to Webster-Stratton (2011), one of the foundations of the emergence of social problems and, most importantly, dealing with them is that the teacher knows what kind of emotional state the students arrive to a lesson, and this is expected from teachers. However, this requires time and it can hardly become a part of the culture of teaching in light of the fact that the observed teachers want to solve the problems as quickly as possible, without shedding light on the underlying reasons in most cases. 


\section{Discussion and limitation}

What was observed draws attention to the effect problems have on the performance (of dealing with the learning material) in the lesson because its course apparently breaks, especially after verbal and physical abuse; in the case of five lessons, teachers indicated that they could not do the tasks designated (in three cases, they were given as homework). Social problems in lessons can also influence students' attitude towards subjects and they can impact their motivation as well. Further observations are planned for the future and, in order not to only compare what was seen with data from earlier questionnaires, we are planning to have questionnaires completed in the observed classes which enables the analysis of several aspects of problem-solving. Such a questionnaire is NEGORI (Kasik et al., 2018), which measures negative orientation, or the Avoidance questionnaire (Kasik et al., 2016). The combined data collection ensures more precise and additional information in order to develop the most complex developmental programme for children and adolescents - and their teachers.

\section{References}

Bedell, J. R., Archer, R. P., \& Marlowe, H. A. Jr. (1980). A description and evaluation of a problem solving skills training programs. In: D. Upper, \& S. M. Ross (Eds.), Behavioral group therapy: An annual review (pp. 3-35). Champaign: Research Press.

Chang, E. E., D’Zurilla, T. J., \& Sanna, L. J. (2004) Social problem solving. Theory, research, and training. Washington, DC: American Psychological Association.

Eskin, M. (2012). Social Problem Solving Therapy in the Clinical Practice. Turkey, Elsevier.

Goldstein, A. P. (1999). The PREPARE curriculum: Teaching prosocial competencies. Champaign, IL: Research Press.

Hunt, J. McV. (1963). Motivation inherent in information processing and action. In O. J. Harvey (Ed.), Motivation and social interaction (pp. 35-94). New York: Ronald Press.

Kasik, L. (2015). Személyközi problémák és megoldásuk. Budapest: Gondolat Kiadó.

Kasik, L., \& Gál, Z. (2014). Mit tekintenek 7, 10 és 14 éves diákok személyközi problémának? Iskolakultúra, 24(9), 3-25.

Kasik, L., \& Gál, Z. (2015). A helyzet- és személyspecifikus problémamegoldás kapcsolata a tudatelméleti müködéssel 4-6 éves korban. Magyar Pedagógia, 115(4), 297-318.

Kasik, L., \& Gál, Z. (2016). Parents' and teachers' opinions of preschool children's social problem-solving and behavioural problems. Early Child Development and Care, 118(10), 1632-1648.

Kasik, L., Gál, Z., \& Tóth, E. (2018). Development and Psychometric Properties of NEGORI (Negative Orientation Questionnaire). Journal of Relationships Research, 9(8), 1-13.

Kasik, L., Guti, K., Tóth, E., \& Fejes, J. B. (2016). Az elkerülés mint folyamat - az Elkerülés kérdőív bemérése 15 és 18 évesek körében. Magyar Pedagógia, 116(2), 219-253.

Petróczi, E. (2007). Kiégés - elkerülhetetlen? Budapest: Eötvös József Könyvkiadó.

Singleton, L. C., \& Asher, S. R. (1977). Peer preferences and social interaction among third-grade children in an integrated school district. Journal of Educational Psychology, 69, 330-336.

Strough, J., \& Keener, E. (2013). Interpersonal problem solving across the life span. In P. Verhaeghen \& C. Hertzog (Eds.), The Oxford handbook of emotion, social cognition, and everyday problem solving during adulthood (pp. 134-152). Oxford University Press: The Oxford Library of Psychology Series.

Webster-Stratton, C. (2011). The Incredible Years. Parents, Teachers, and Children's Training Series. Program Contetnt, Methods, Research and Dissemination 1980-2011. file:///The-IncredibleYears-Parent-Teacher-Childrens-Training-Series-1980-2011p.pdf 